\title{
Preserved activation of thyrotropin receptor antibody to stimulate thyroid function despite long-term treatment in euthyroid patients with Graves' disease
}

\author{
Masako Akuzawa, Masami Murakami, Masanobu Yamada, Tetsurou Satoh, Hiroyuki Shimizu and \\ Masatomo Mori \\ First Department of Internal Medicine, Gunma University School of Medicine, Maebashi 371, Japan \\ (Correspondence should be addressed to M Mori)
}

\begin{abstract}
Clinical evaluation was conducted to ascertain whether thyrotropin receptor antibody (TRAb) in the normal range may still be involved in the regulation of thyroid function after prolonged treatment for Graves' disease. All patients $(n=33)$ were treated with antithyroid drugs for an average of 10.6 years and were under euthyroid conditions in which normal blood levels of tri-iodothyronine $\left(\mathrm{T}_{3}\right)$ were significantly correlated with blood thyrotropin (TSH) levels, but not with titers of TRAb. A significant correlation was observed between TRAb titer and thyroid-stimulating antibody (TSAb) activity. In contrast, this correlation was not found in normal subjects. After administration of $\mathrm{T}_{3}(75 \mu \mathrm{g}$ daily for 8 days), the patients showed increased levels of $\mathrm{T}_{3}$ with concomitant suppression of TSH levels. Under these conditions, linear regression analysis showed significant correlations of TRAb titer and TSAb activity with 24 -h thyroid radioiodine uptake $(r=0.641$ and 0.621 respectively, $P<0.01)$, in contrast to declining blood thyroxine levels. Moreover, the immunoglobulin G $(\operatorname{IgG})$ of the patients precipitated to a greater extent than $\mathrm{IgG}$ from normal subjects a peptide consisting of the amino acid sequence near the terminus of the human TSH receptor. These findings indicated that TRAb at normal levels possessed significant unremitting activities on thyroid function despite long-term treatment in euthyroid patients with Graves' disease.
\end{abstract}

European Journal of Endocrinology 138 281-285

\section{Introduction}

Graves' disease is an autoimmune anti-receptor disease and is characterized by abnormal immunoglobulin G (IgG) that can not only displace thyrotropin (TSH) binding to thyroid plasma membranes (TSH receptor antibody, TRAb), but can also stimulate thyroid functions (thyroid-stimulating antibody, TSAb) (1-3). Our previous observations (4-6) have suggested that the undeniable amino acid sequence at the $\mathrm{N}$-terminal site of the extracellular domain of the TSH receptor is the immunogenic region for IgG in Graves' disease but not in other thyroid disorders. Moreover, immunization with a peptide specific to Graves' IgG was found to produce marked TSAb activity in rabbits (6). As this abnormal IgG contributes to increased thyroid gland function in the hyperthyroid state (7-10), assessment of TRAb enables physicians to make an accurate diagnosis of the disease. Under treatment with antithyroid drugs $\mathrm{TRAb}$ titers decrease to normal levels. Although the efficient duration of this treatment is still controversial (11), prolonged rather than short-term treatment may improve the remission rate of this disease (10). At the end of a course of long-term therapy, determination of
TRAb may be important to forecast the patient's prognosis $(7-10,12,13)$, but this has not become standard practice due to difficulties in obtaining consistent results on testing $(14,15)$ or to insensitivity of the assay. Interesting results have come from Peakman et al. (16) who reported that T-lymphocytes remained activated in long-term remission of Graves' disease. Furthermore, IgG of normal persons has been observed to be capable of binding the TSH receptor $(17$, 18). However, there is little information available as to whether TRAb in the normal range exhibits persistent functions of the thyroid gland and whether the patient's IgG may continue to recognize the possible immunogenic region on TSH receptors. The present study was performed to obtain an insight into the characteristics of IgG in Graves' patients receiving prolonged and effective treatment with antithyroid drugs.

\section{Patients and methods}

\section{Subjects}

Thirty-three patients with Graves' disease (27-77 years old (average age $51.6 \pm 2.4$ years); male:female ratio 
6:27) were treated with methimazole $(n=22)$ and propylthiouracil $(n=11)$, the daily maintenance doses to maintain clinical euthyroid states being $5.7 \pm 0.4$ and $51.5 \pm 5.5 \mathrm{mg}$ respectively. All laboratory findings were within the normal range. The duration of treatment ranged from 3 to 19 years (average 10.6 1.1 years). Eighteen normal healthy subjects (average age $49.9 \pm 1.4$ years; male:female ratio 3:15) were included in this study. All subjects gave their informed consent in accordance with the Helsinki Declaration of 1975, as revised in 1983 .

\section{Thyroid function tests}

Serum total thyroxine $\left(\mathrm{T}_{4}\right)$ and tri-iodothyronine $\left(\mathrm{T}_{3}\right)$ levels were measured using commercially available enzyme-immunoassay kits (Boehringer-Mannheim enzyme-immunoassay $\mathrm{T}_{4}$ and $\mathrm{T}_{3}$ kits, BoehringerMannheim, Tokyo, Japan). Serum TSH was measured with a radioimmunoassay kit (Daiichi radioimmunoassay TSH kit, Daiichi Radio-Isotope Co., Japan). The normal ranges of serum $\mathrm{T}_{4}, \mathrm{~T}_{3}$, and $\mathrm{TSH}$ were $72.1-$ $154.4 \mathrm{nmol} / \mathrm{l}, \quad 1.23-3.07 \mathrm{nmol} / \mathrm{l}$, and $0.6-5.5 \mathrm{mU} / \mathrm{l}$ respectively. Due to the elimination of the influence of endogenous TSH on thyroid radioiodine uptake (RIU), the 24-h thyroid uptake of ${ }^{123} \mathrm{I}$ (normal range, below $35 \%$ in $24 \mathrm{~h}$ ) was determined by the standard procedure after oral administration of $75 \mu \mathrm{g} \mathrm{T}$ daily (t.i.d.) for 8 days, as described elsewhere $(19,20)$.

\section{Determination of immunoglobulin}

TRAb titers were measured using Smith's kit (Baxter R.S.R. Ltd, Cardiff, UK) using labeled bovine TSH and porcine thyroid membranes as described previously (12), and TSAb activities were measured using porcine thyroid cells (8). The variations of these intra- and interassays were less than $12 \%$. When TRAb titer and TSAb activity were less than $15 \%$ and $160 \%$ respectively of normal controls, they were designated in the normal range. This range is comparable to that of previous observations $(8,12,20)$.

\section{Immunoprecipitation of the human TSH receptor-derived peptide}

Detailed recognition by IgG of the TSH receptor was determined using a synthetic peptide corresponding to the amino acid sequence (amino acids $32-56$ ) at the $\mathrm{N}$-terminus of the extracellular domain of human TSH receptor, as described previously (4). Briefly, $50 \mu \mathrm{l}$ IgG $(0.5 \mathrm{mg})$, which were separated using a DEAE column (Bio-Rad Laboratories, Richmond, CA, USA), were incubated with $100 \mu \mathrm{l}^{125}$ I-labeled synthetic peptide (approximately 20000 c.p.m.) in phosphate-buffered saline (PBS; $0.01 \mathrm{~mol} / \mathrm{l} \mathrm{PO}_{4}, 0.15 \mathrm{~mol} / \mathrm{l} \mathrm{NaCl}, \mathrm{pH} 7.5$ ) containing $0.25 \%$ bovine serum albumin, and $150 \mu \mathrm{l}$ incubation buffer (PBS containing $0.05 \mathrm{~mol} / \mathrm{l}$ EDTA,
$\mathrm{pH} 7.5)$. After incubation at $4{ }^{\circ} \mathrm{C}$ for $48 \mathrm{~h}$, the precipitates were obtained by adding $500 \mu \mathrm{l} 8 \mathrm{mg} / \mathrm{ml}$ bovine $\gamma$-globulin and $500 \mu \mathrm{l} 30 \%$ polyethylene glycol (molecular mass 6000) followed by centrifugation at $2000 \mathrm{~g}$ for $30 \mathrm{~min}$, and were counted for $\gamma$-rays. This assay was done as a single assay to avoid the interassay variation. The intra-assay variation was $3.6 \%$. Due to the limited amount of blood obtained, IgGs from 13 of the patients (aged 49.0 \pm 4.1 years; male:female ratio 3:10) were examined and compared with those from 10 normal subjects (aged $48.8 \pm 3.0$ years; male:female ratio 3:7).

\section{Results}

Table 1 shows thyroid function parameters in Graves' disease before and after $\mathrm{T}_{3}$ administration. Blood levels of $\mathrm{T}_{4}, \mathrm{~T}_{3}$ and TSH were within the normal range before $\mathrm{T}_{3}$ administration. Blood levels of TSH showed a significant negative correlation with those of $\mathrm{T}_{3}$ $(r=-0.492, \quad P<0.05)$. This was similar to that observed in normal subjects (TSH vs $\mathrm{T}_{3}, r=-0.596$, $P<0.05)$. In Graves' patients, neither TRAb titer nor $\mathrm{TSAb}$ activity was significantly correlated to thyroid hormone concentration (vs $\mathrm{T}_{3}$ levels, $r=-0.023$ and -0.033 respectively). In contrast, a significant correlation was found between TRAb titer and TSAb activity $(r=0.504, P<0.01)$ as shown in Fig. 1. However, this significant correlation did not occur in normal subjects (TRAb vs TSAb, $r=0.036, P>0.05$ ).

In patients with Graves' disease, oral administration of $\mathrm{T}_{3}$ caused an increase in blood $\mathrm{T}_{3}$ levels, reaching the hyperthyroid state, followed by significant decreases in TSH, indicating the suppression of TSH secretion from the anterior pituitary. $\mathrm{T}_{4}$ levels were also suppressed. Figure 2 shows the relationship between the rate of $\mathrm{T}_{3}$-induced $\mathrm{T}_{4}$ suppression and TRAb titer and TSAb activity in individual patients. There were no significant relationships between these parameters $\left(\mathrm{T}_{4}\right.$ suppression rate vs TRAb titer and TSAb activity, $r=0.217$ and 0.186 respectively). This reflects no activation of TRAb on $\mathrm{T}_{4}$ secretion from the thyroid gland. In contrast, as shown in Fig. 3, significant positive correlations were

Table 1 Parameters of thyroid function before and after $T_{3}$ administration in long-term treated patients with Grave's disease. Results are expressed as means \pm S.E.M. $(n=33)$.

\begin{tabular}{lcc}
\hline Parameters & $\begin{array}{c}\text { Before } \\
\mathbf{T}_{3} \text { administration }\end{array}$ & $\begin{array}{c}\text { After } \\
\mathbf{T}_{3} \text { administration }\end{array}$ \\
\hline $\mathrm{T}_{4}(\mathrm{nmol} / \mathrm{l})$ & $125.0 \pm 3.9$ & $100.1 \pm 4.2^{*}$ \\
$\mathrm{~T}_{3}(\mathrm{nmol} / \mathrm{l})$ & $2.58 \pm 0.06$ & $5.42 \pm 0.31^{*}$ \\
$\mathrm{TSH}(\mathrm{mU} / \mathrm{l})$ & $2.15 \pm 0.27$ & $0.07 \pm 0.01^{*}$ \\
$\mathrm{TRAb}(\%)$ & $6.6 \pm 1.3$ & $5.8 \pm 0.8$ \\
$\mathrm{TSAb}(\%)$ & $111.3 \pm 4.8$ & $109.5 \pm 3.5$ \\
$\mathrm{RIU}(\%)$ & - & $9.1 \pm 1.0$
\end{tabular}

${ }^{*} P<0.01$, significantly different from the values before $\mathrm{T}_{3}$ administration in each group (Student's $t$-test). 


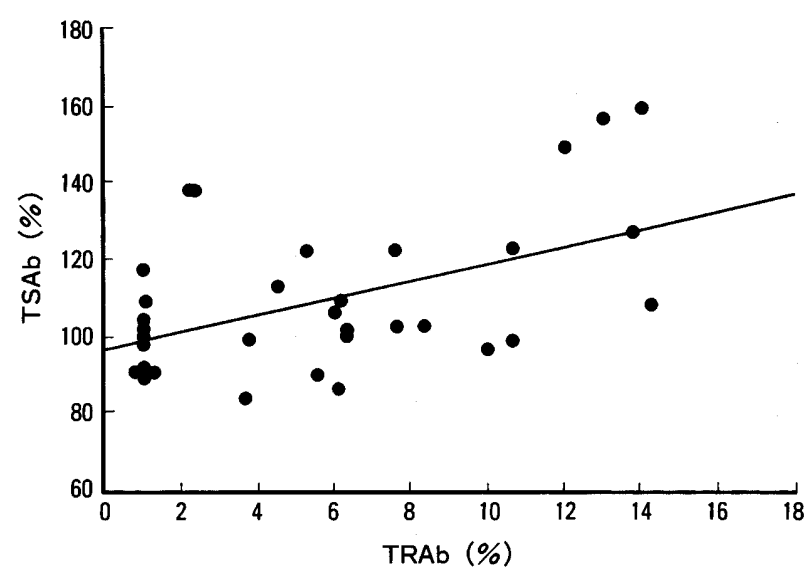

Figure 1 Relationship between TRAb titer and TSAb activity in long-term treated euthyroid patients with Graves' disease.

observed between the ratio of $\mathrm{T}_{3}$-suppressive thyroid RIU and TRAb titer and TSAb activity in the patients $(r=0.641$ and 0.621 respectively, $P<0.01)$, indicating that TRAb stimulates an iodide-transport function of

(a)

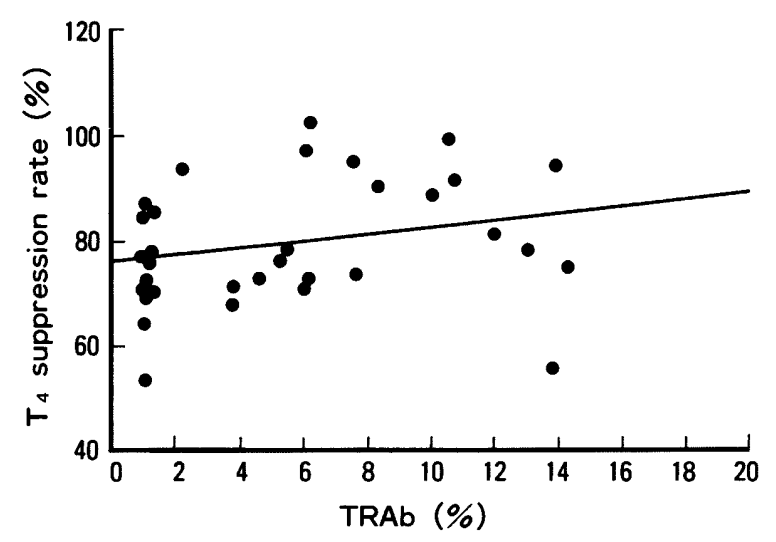

(b)

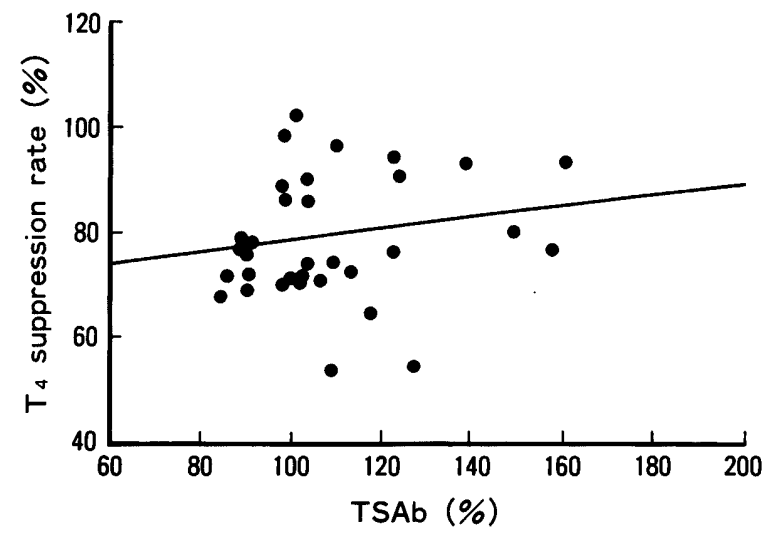

Figure 2 Relationship between TRAb titer and TSAb activity and $T_{3}$-induced $T_{4}$ suppression rate. (a) $T_{4}$ suppression rate vs TRAb titer; (b) $\mathrm{T}_{4}$ suppression rate vs TSAb activity. the thyroid gland in euthyroid Graves' disease. These data imply that Graves' IgG might possess many different and separate actions on thyroid functions including iodide transport, thyroglobulin synthesis, thyroglobulin iodination, coupling reaction of iodotyrosines, iodothyronine formation and thyroid hormone secretion.

The IgG from patients' with Graves' disease precipitated the synthetic TSH receptor-related peptide to a significantly greater extent than normal IgG (1565 \pm 49 vs $1207 \pm 40$ counts per min, $P<0.01)$, as shown in Fig. 4.

\section{Discussion}

The present study demonstrated that TRAb titer in the normal range showed a significant positive correlation with some thyroid functions after prolonged treatment with antithyroid drugs in Graves' disease. Although in untreated hyperthyroid patients increased TRAb titers have been shown to be related to blood concentrations of thyroid hormones $(9,12)$, no significant correlation

(a)

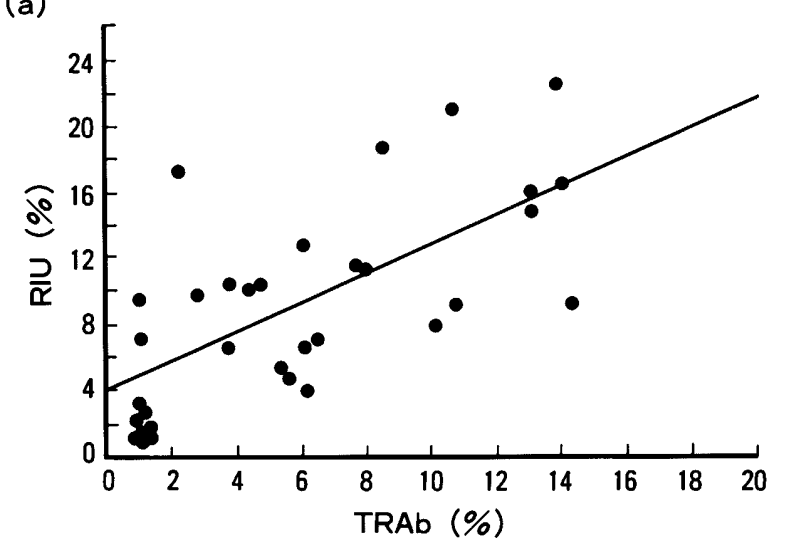

(b)

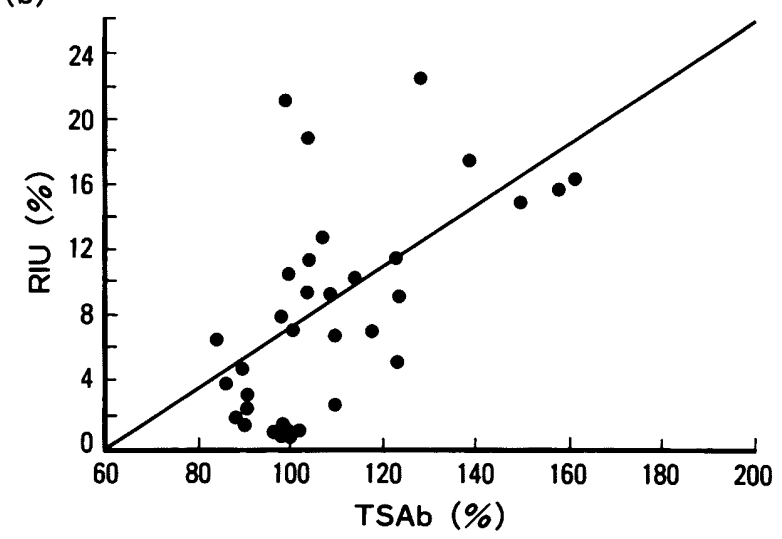

Figure 3 Relationship between TRAb titer and TSAb activity and thyroid RIU rate after $\mathrm{T}_{3}$ administration. (a) Thyroid RIU vs TRAb titer; (b) thyroid RIU vs TSAb activity. 


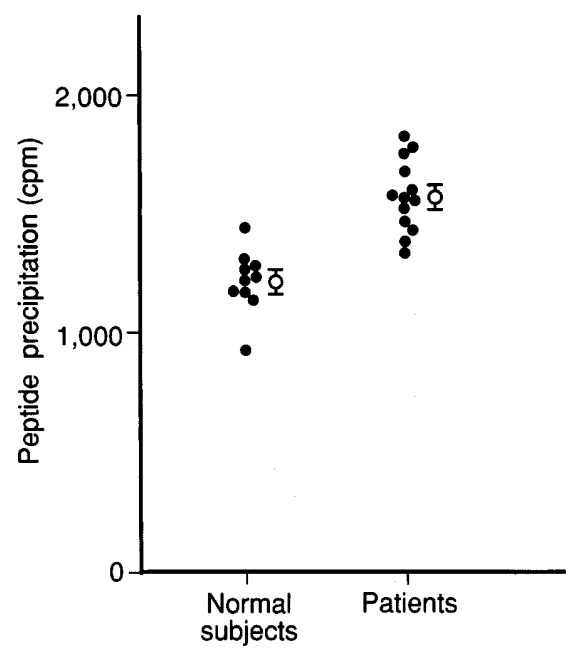

Figure 4 Immunoprecipitation of a human TSH receptor-related peptide. The peptide consisting of the amino acid sequence near the $\mathrm{N}$-terminus of the TSH receptor was incubated with IgG from normal subjects $(n=10)$ and from patients with Graves' disease $(n=13)$. Open circles and vertical lines represent means \pm S.E.M.

was found between TRAb titer and thyroid hormone levels in the euthyroid patients examined here. In contrast, the blood concentrations of $\mathrm{T}_{3}$ showed a significant inverse correlation with blood levels of TSH as observed in normal subjects, the data implying that thyroid hormone levels were regulated by TSH secreted from the anterior pituitary but not by activities of either TRAb or TSAb in euthyroid Graves' disease. TRAb and TSAb activities showed no correlation with $\mathrm{T}_{3}$-induced $\mathrm{T}_{4}$ suppression. As the suppression of $\mathrm{T}_{4}$ levels after $\mathrm{T}_{3}$ administration reflects a decrease in $\mathrm{T}_{4}$ secretion from the thyroid gland (21), the present results suggest that thyroid hormone secretion from the thyroid gland was also basically unconnected to the activities of TRAb or TSAb in euthyroid Graves' disease.

The existence of a positive relationship between TRAb titer and TSAb activity has remained controversial $(1,22)$. In the present study, a significant correlation between these two parameters was not observed in normal subjects. However, there was an apparent correlation between the TRAb titer and TSAb activity in euthyroid patients with Graves' disease. Moreover, these two parameters within the normal range were significantly correlated with the rate of thyroid RIU after $\mathrm{T}_{3}$ administration under conditions in which endogenous TSH secretion was apparently suppressed. These results are in agreement with previous observations that activities of Graves' IgG have a significant relationship with thyroid RIU in untreated patients in the hyperthyroid state (9). These data imply that Graves' IgG stimulates iodide transport, part of the function of the thyroid. IgG from normal individuals has been found capable of binding TSH receptors in the thyroid membranes $(17,18)$, but there is no evidence that normal IgG affects thyroid functions (23). Therefore,
Graves' IgG is characterized by persistent activation of the thyroid functions in vitro and in vivo despite its normal levels during long-term treatment.

The present results also show that the recognition activities of patients' IgG for the possible immunogenic region on the extracellular domain of the human TSH receptor were preserved, although their connection with TRAb titer and TSAb activity remains to be resolved. The peptide utilized here was synthesized on the basis of the strong turn potential indicated by ChouFasman secondary protein structure, the heightened antigenicity of the individual amino acid composition, and sequential amino acids with low homology to the amino acid sequence of luteinizing hormone/chorionic gonadotropin receptor, as described previously (4). Recognition of this peptide sequence is specific to IgG from Graves' patients, but is not recognised by those from Hashimoto's thyroiditis, subacute thyroiditis, or goitrous patients (5). These observations are compatible with the findings of Wadsworth et al. (24) who reported that the amino acid sequence near the amino terminus of the TSH receptor was an important site for the function of TSAb. Furthermore, we observed that immunization with a peptide identical to that tested here produced significant TSAb activity in rabbits (6). In conjunction with these observations, the present study supports the concept that TRAb still recognizes the TSH receptor even in euthyroid patients after prolonged treatment.

The present observations are in agreement with the previous results that T-lymphocytes in peripheral blood were activated in Graves' patients with long-term remission as compared with normal controls (16). Taken together, the present results support the possibility that the activated immunological mechanisms (3, 16) are responsible for activation of peripheral IgG with a specific immunogenic region on the TSH receptor that may, in turn, be connected with thyroid stimulation in Graves' disease after long-term treatment.

It will be of interest to assess whether the patients observed here relapse or go into remission after withdrawal of treatment.

\section{Acknowledgements}

This work was supported in part by the Clinical Research Special Fund-1996, Gunma University Hospital, Maebashi Japan and a grant-in-aid for Research from the Ministry of Education, Science and Culture of Japan.

\section{References}

1 Smith BR, McLachlan SM \& Furumaniak J. Autoantibodies to the thyrotropin receptor. Endocrine Reviews 19889 106-121.

2 McKenzie JM \& Zakarija M. The clinical use of thyrotropin receptor antibody measurements. Journal of Clinical Endocrinology and Metabolism 198969 1093-1096.

3 Weetman AP, Yateman ME, Earley PA, Black CM, Reimer CB, Williams RC, Shine B \& Marshall NJ. Thyroid-stimulating 
antibody between different immunoglobulin G subclasses. Journa of Clinical Investigation $199086723-727$.

4 Murakami M \& Mori M. Identification of immunogenic regions in human thyrotropin receptor for immunoglobulin $G$ of patient with Graves' disease. Biochemical and Biophysical Research Communications $1990171512-518$.

5 Murakami M, Miyashita K, Yamada M, Iriuchijima T \& Mori M. Precipitation of thyrotropin receptor-related peptides by immunoglobulin G of patients with Hashimoto's thyroiditis. Life Sciences $1994551209-1217$.

6 Murakami M, Miyashita K, Mizuma H, Yamada M, Iriuchijima T, Takeuchi T \& Mori M. Discrete characterization of antibodies raised against thyrotropin receptor-related peptides whose sequence are not conserved in the luteinizing hormone/chorionic gonadotropin receptor. Journal of Clinical Endocrinology and Metabolism 199681 1747-1752.

7 Rapoport B, Greenspan FS, Filetti S \& Pepitone M. Clinical experience with a human thyroid cell bioassay for thyroidstimulating immunoglobulin. Journal of Clinical Endocrinology and Metabolism 198458 332-338.

8 Kasagi K, Konishi J, Arai K, Misaki T, Iida Y, Endo K \& Torizuka K. A sensitive and practical assay for thyroid-stimulating antibodies using crude immunoglobulin fractions precipitated with polyethylene glycol. Journal of Clinical Endocrinology and Metabolism $198662855-862$.

9 Benker G, Kotulla P, Kendall-Taylor P, Emrich D \& Reinwein D. TSH binding-inhibiting antibodies in hyperthyroidism: relationship to clinical signs and hormone levels. Clinical Endocrinology $19893019-28$.

10 Allannic H, Fauchet R, Orgiazzi J, Madec AM, Genetec B, Lorcy Y, LeGuerrier AM, Delambre C \& Derennes V. Antithyroid drugs and Graves' disease: a prospective randomized evaluation of the efficacy of treatment duration. Journal of Clinical Endocrinology and Metabolism 199070 675-679.

11 Reinwein D, Benker G, Lazarus JH \& Alexander D. A prospective randomized trial of antithyroid drug dose in Graves' disease therapy. Journal of Clinical Endocrinology and Metabolism 199376 $1516-1521$.

12 Kasagi K, Tamai H, Morita T, Hidaka A, Hataby H, Misaki T, Iida Y, Ishihara T, Ikekubo K, Kuma K \& Konishi J. Role of thyrotropin receptor antibodies in the development of hyperthyroidism: follow-up studies on nine patients with Graves' disease. Journa of Clinical Endocrinology and Metabolism 198968 1189-1194.

13 Winsa B, Rastad J, Akerstrom G, Johansson H, Westermark K \& Karlsson FA. Retrospective evaluation of subtotal and total thyroidectomy in Graves' disease with and without endocrine ophthalmopathy. European Journal of Endocrinology 1995132 406-412.
14 Solomon B, Glinoer D, Lagasse R \& Wartofsky L. Current trends in management of Graves' disease. Journal of Clinical Endocrinology and Metabolism 199070 1518-1524.

15 Feldt-Rasmussen U, Schleusener H \& Carayon P. Meta-analysis evaluation of the impact of thyrotropin receptor antibodies on long term remission after medical therapy of Graves' disease. Journal of Clinical Endocrinology and Metabolism 1994 78 98-102.

16 Peakman M, Hussain M, Cundy T \& Vergani D. Increased activated T-lymphocytes and normal thyrotropin receptor antibody levels in Graves' disease in long-term remission. Journal of Clinical Laboratory and Immunology 198930 1-5.

17 Beall GN, Chopra IJ, Solomon DH \& Kruger SR. Serum protein inhibition of thyrotropin binding to human thyroid tissue. Journal of Clinical Endocrinology and Metabolism 1978 47 967-973.

18 Brown RS, Kertilers BL \& Reichlin S. Partial purification and characterization of thyrotropin binding inhibitory immunoglobulins from normal human plasma. Journal of Clinical Endocrinology and Metabolism 198356 156-163.

19 Kobayashi I, Ishii H \& Mori M. $\mathrm{T}_{4}$ suppression test involving 24-hour thyroidal ${ }^{131}$ I uptake in patients with Graves' disease compared with the $\mathrm{T}_{3}$ suppression test. Endocrine Journal 198431 101-108.

20 Tamai H, Kasagi K, Morita T, Hidaka A, Kuma K, Konishi J, Kumagai LF \& Nagataki S. Thyroid response, especially to thyrotropin-binding inhibitory immunoglobulins, in euthyroid relatives of patients with Graves' disease: a clinical follow-up. Journal of Clinical Endocrinology and Metabolism 199071 210215.

21 Duick DS, Stein RB, Warren DW \& Nicoloff JT. The significance of partial suppressibility of serum thyroxine by triiodothyronine administration in euthyroid man. Journal of Clinical Endocrinology and Metabolism 197541 229-234.

22 Sugenoya A, Kidd A, Row VV \& Volpe R. Correlation between thyrotropin-displacing activity and human thyroid-stimulating activity by immunoglobulins from patients with Graves' disease and other thyroid disorders. Journal of Clinical Endocrinology and Metabolism 197948 398-402.

23 Kleinmann RE, Braverman LE, Vagenakis AG, Butcher RW \& Clark RB. A new method for measurement of human thyroidstimulating immunoglobulin. Journal of Laboratory and Clinical Medicine 198095 581-589.

24 Wadsworth HL, Chazenbalk GD, Nagayama Y, Russo D \& Rapoport B. An insertion in the human thyrotropin receptor critical for high affinity hormone binding. Science 1990249 1423-1425.

Received 26 May 1997

Accepted 8 December 1997 